\title{
A comparative study of using glibenclamide versus insulin in the treatment of gestational diabetes mellitus and its outcome
}

\author{
P. S. Rao*, Sujata Datta, S. Prajwal
}

Department of Obstetrics and Gynecology, Command Hospital, Bangalore, Karnataka, India

Received: 03 February 2017

Revised: 04 March 2017

Accepted: 07 March 2017

\section{*Correspondence:}

Dr. Rao PS,

E-mail: doctorpsrao@gmail.com

Copyright: () the author(s), publisher and licensee Medip Academy. This is an open-access article distributed under the terms of the Creative Commons Attribution Non-Commercial License, which permits unrestricted non-commercial use, distribution, and reproduction in any medium, provided the original work is properly cited.

\begin{abstract}
Background: Gestational diabetes mellitus(GDM) is defined as carbohydrate intolerance of variable severity with onset or first recognition during pregnancy. This study aims at determining the efficacy of the glibenclamide versus insulin in achieving the adequate glycemic control and to analyze the maternal and fetal outcomes and to determine the failure rate of glibenclamide, patient compliance and overall cost of the treatment

Methods: This study was carried out for a period of 22 months at Command Hospital Air Force, Bangalore in Dept. of OBG. Women with GDM whose glycemic control was not achieved with medical nutrition therapy with fasting blood sugar (FBS) values $\geq 105 \mathrm{mg} / \mathrm{dl}$ and 2 hour post prandial blood sugar (PP) value $\geq 140 \mathrm{mg} / \mathrm{dl}$ were selected and randomized for treatment either glibenclamide or insulin (50 in each group).

Results: The age of the patients in this study ranged from 23 to 33 years. The mean age in glibenclamide group was 27.32 ( $\mathrm{SD} \pm 2.84$ ) where as in insulin group was $26.30(\mathrm{SD} \pm 3.01)$. The mean plasma glucose level achieved with glibenclamide was fasting $-87.62 \mathrm{mg} / \mathrm{dl}$, post prandial $-116.44 \mathrm{mg} / \mathrm{dl}$, before lunch $-95.62 \mathrm{mg} / \mathrm{dl}$, after lunch -115.80 $\mathrm{mg} / \mathrm{dl}$, before dinner-91.96 mg/dl, after dinner $-116.64 \mathrm{mg} / \mathrm{dl}, 3 \mathrm{AM}-84.42 \mathrm{mg} / \mathrm{dl}$ and next day fasting $-86.30 \mathrm{mg} / \mathrm{dl}$ in comparison with insulin where fasting- $85.54 \mathrm{mg} / \mathrm{dl}$, post prandial $-114.14 \mathrm{mg} / \mathrm{dl}$, before lunch - 87.08, after lunch $-112.82 \mathrm{mg} / \mathrm{dl}$, before dinner-86.76 mg/dl and after dinner $-114.18 \mathrm{mg} / \mathrm{dl}, 3 \mathrm{AM}-81.16 \mathrm{mg} / \mathrm{dl}$ and next day fasting was $86.72 \mathrm{mg} / \mathrm{dl}$ which is statistically significant. The incidence of maternal and neonatal morbidities was comparable in both the group. $4 \%$ percent of patient treated with glibenclamide had treatment failure. The cost of the treatment and compliance was better with glibenclamide.

Conclusions: It has been concluded that glibenclamide is effective as insulin in achieving adequate glycemic control with no significant maternal and fetal morbidity and mortality.
\end{abstract}

Keywords: Cost and compliance, Efficacy, Gestational diabetes mellitus, Glibenclamide, Insulin

\section{INTRODUCTION}

Gestational diabetes mellitus (GDM) is one of the common medical disorders complicating the pregnancy. Pregnancy induces progressive changes in the maternal carbohydrate metabolism to meet the growing demands of the ingrowing foetus and the mother herself. As the pregnancy advances, the insulin resistance and diabetogenic stress due to hormones like human placental lactogen (HPL), progesterone, prolactin and cortisol necessitate compensatory increase in insulin secretion. When this compensation is inadequate gestational diabetes mellitus ensues.

Gestational diabetes (GDM) is defined as carbohydrate intolerance of variable severity with onset or first recognition during pregnancy. ${ }^{1}$ The significance of GDM is that two generations are at risk of developing diabetes 
in future .Women with a history of GDM are at increased risk of future diabetes, predominately type 2 diabetes, as their children thus GDM offers an important opportunity for diagnosis and implementation of clinical strategies for diabetes prevention. ${ }^{2}$

Historically, insulin has been the therapeutic agent of choice for controlling hyperglycaemia in pregnant women. However, difficulty in medication administration with multiple daily injections, potential for hypoglycaemia, and increase in appetite and weight make this therapeutic option cumbersome for many pregnant patients. While insulin is the gold standard therapy for controlling maternal glycaemia, the increasing use of oral diabetic agents such as metformin and glibenclamide begun to change standard care.

Oded Langer et al evaluated in women with gestational diabetes, glibenclamide is a clinically effective alternative to insulin therapy. ${ }^{3}$ The daily blood glucose concentrations, and glycosylated haemoglobin values were similar between patients on glibenclamide and insulin. The failure rate was $4 \%$ in the glibenclamide patients, thus requiring the need to switch to insulin. There were no differences in the infants who were large for gestational age or with macrosomia, RDS, hypoglycaemia, admission to the neonatal intensive care unit or foetal anomalies.

Goetz et al compared the costs associated with glibenclamide versus insulin therapy. Glibenclamide was found to be significantly less costly than insulin. ${ }^{4}$ Anjalakshi et al concluded that insulin is expensive and many women find it inconvenient to take insulin. ${ }^{5}$

Mukhopadhyay Partha et al concluded that the use of oral agents is a pragmatic alternative to insulin therapy in cases of gestational diabetes because of similar glycaemic control, ease of administration and better patient compliance due to non-invasive treatment. ${ }^{6}$

Temple et al recently conducted over Indian population from a Department of OBG of a teaching hospital and reported that $93.8 \%$ and $97.1 \%$ of patients in glibenclamide and insulin groups obtained adequate glycaemic control respectively. ${ }^{7}$

This study is done to find the effectiveness of glibenclamide versus insulin regarding the glycaemic control, maternal and foetal outcome, compliance and acceptance by the patients.

\section{METHODS}

This prospective randomised observational clinical study was carried out for a period of 22 month (from October 2014 to August 2016) at Command Hospital Air Force (CHAF), Bangalore in Department of Obstetrics and Gynaecology. CHAF is a tertiary care hospital and Dept. of Obstetrics \& Gynaecology is a referral centre for care of patients with obstetrics and gynaecological problems, from other military hospital/ institutions in Karnataka and neighbouring states.

100 patients of GDM were recruited into a randomized trial and divided into two groups of 50 each using computer generated randomisation software (research randomiser) and one group was treated with insulin and other with glibenclamide and their health status and outcome after treatment was compared. All antenatal patients were screened for GDM except those who had pre-existing diabetes. As per institutional policy, every patient was advised 75 gram OGTT at her first antenatal visit.

However, the test was deferred till the nausea and vomiting of early pregnancy subsided. In women with excessive nausea and vomiting, fasting and postprandial plasma glucose were asked for. However, all women even who had normal OGTT result in the first antenatal visit were subjected to repeat OGTT between 2428 weeks period of gestation. IADPSG criteria is used for the diagnosis.

Women with GDM whose glycaemic control was not achieved with medical nutrition therapy, and fasting blood sugar (FBS) values $\pm 105 \mathrm{mg} / \mathrm{dl}$ and 2 hour postprandial blood sugar (PP) value $\pm 140 \mathrm{mg} / \mathrm{dl}$ after MNT, were selected. Patients having following disorders overt diabetes, heart diseases, renal disorders, chronic hypertension, known case of allergic to sulfonylureas and women on steroid treatment were excluded from the study.

All the patients who were diagnosed to have GDM were advised to take medical nutrition therapy (MNT). Daily calorie requirement for an average Indian woman is approximately $1600 \mathrm{kcal} /$ day and she requires about 1700 , 1800 and $1900 \mathrm{kcal} /$ day in Ist, IInd and IIIrd trimester of pregnancy respectively. After three days of MNT for inpatient and seven days for outpatient, all patients underwent six point plasma glucose profile which included-fasting, post-prandial, before lunch, after lunch, before dinner, after dinner.

The method used for determination of plasma glucose level is GOD-POD method. The target glucose levels for pre-meal sample were taken as $95 \mathrm{mg} / \mathrm{dl}$ and those for post meal samples were taken as $120 \mathrm{mg} / \mathrm{dl}$. However, three or more abnormal values were considered as an indicator of failed medical nutrition therapy and were started with either glibenclamide or insulin.

Glibenclamide in a dosage starting from $2.5 \mathrm{mg}$ once or twice daily to $\max 10 \mathrm{mg}$ BD. Further repeat plasma glucose profile was ordered after three days of instituting glibenclamide therapy to re-evaluate the plasma glucose control and dose was titrated accordingly, and again the plasma glucose profile was repeated 1 week after the dose adjustment and thereafter every three weekly or 
more frequently depending upon the glycaemic control. Patients whose plasma glucose control was inadequate with adequate MNT and maximum dose of glibenclamide for one week were shifted to insulin therapy. Patients with deranged plasma profile with three or more abnormal value with fasting value exceeding $105 \mathrm{mg} / \mathrm{dl}$ or postprandial $>140 \mathrm{mg} / \mathrm{dl}$ were considered to therapy as per randomisation or who failed with glibenclamide therapy were treated with human insulin mixtard.

The requirement of insulin for a patient was calculated as 0.7, 0.8 and 0.9 units/kg body weight for $1^{\text {st }}, 2^{\text {nd }}$ and $3^{\text {rd }}$ trimester respectively. Only $2 / 3 \mathrm{rd}$ of the above calculated dose was administered, of which $2 / 3$ rd was administered subcutaneously in the morning and remaining in the evening.

All patients on insulin and glibenclamide therapy underwent an eight-point plasma glucose profile after three days, which included 3AM and next day fasting value. Repeat plasma glucose profile was done one week after the final dose adjustment and every three weekly or two weekly depending upon glycaemic control.

All GDM patients were advised to undergo on OGTT with $75 \mathrm{~g}$ glucose at 6 weeks post-partum and were termed as either diabetic or non-diabetic. Chi square test was used for statistical analysis

\section{RESULTS}

100 patients were recruited for the study.

Table 1, shows the age distribution of the study population in both groups. The age of the patients in this study ranged from 23 to 33 years. The mean age in glibenclamide group was $27.32(\mathrm{SD} \pm 2.84)$ where as in insulin group was $26.30(\mathrm{SD} \pm 3.01)$.

Table 1: Age distribution.

\begin{tabular}{|lll|}
\hline Age (years) & $\begin{array}{l}\text { Glibenclamide } \\
\text { group }\end{array}$ & Insulin group \\
\hline $21-25$ & $14(28)$ & $23(46)$ \\
\hline $26-30$ & $31(62)$ & $19(38)$ \\
\hline $31-35$ & $05(10)$ & $08(16)$ \\
\hline Total & 50 & 50 \\
\hline Mean \pm SD & $27.32 \pm 2.84$ & $26.30 \pm 3.01$ \\
\hline
\end{tabular}

Table 2 shows the mean plasma glucose level before treatment in each group.

In glibenclamide group, fasting was $107 \mathrm{mg} / \mathrm{dl}$, post prandial was $142 \mathrm{mg} / \mathrm{dl}$, before lunch was $103 \mathrm{mg} / \mathrm{dl}$, after lunch was $139 \mathrm{mg} / \mathrm{dl}$, before dinner was $105 \mathrm{mg} / \mathrm{dl}$ and after dinner was $140 \mathrm{mg} / \mathrm{dl}$ and whereas in insulin group, fasting was $108 \mathrm{mg} / \mathrm{dl}$, post prandial was $141 \mathrm{mg} / \mathrm{dl}$, before lunch was $103 \mathrm{mg} / \mathrm{dl}$, after lunch was $142 \mathrm{mg} / \mathrm{dl}$, before dinner was $106 \mathrm{mg} / \mathrm{dl}$ and after dinner was $141 \mathrm{mg} / \mathrm{dl}$.

Table 3 shows the mean plasma glucose level after 1 week of treatment in each group. In glibenclamide group fasting was $91.20 \mathrm{mg} / \mathrm{dl}$, postprandial was $117.38 \mathrm{mg} / \mathrm{dl}$, before lunch was $94.06 \mathrm{mg} / \mathrm{dl}$, after lunch was 114.68 $\mathrm{mg} / \mathrm{dl}$,before dinner was $92.38 \mathrm{mg} / \mathrm{dl}$, after dinner was $115.52 \mathrm{mg} / \mathrm{dl}, 3 \mathrm{AM}$ was $82.68 \mathrm{mg} / \mathrm{dl}$ and next day fasting was $86.28 \mathrm{mg} / \mathrm{dl}$ whereas in insulin group, fasting was $85.16 \mathrm{mg} / \mathrm{dl}$, postprandial was $112.12 \mathrm{mg} / \mathrm{dl}$, before lunch was $86.70 \mathrm{mg} / \mathrm{dl}$, after lunch was $111.02 \mathrm{mg} / \mathrm{dl}$, before dinner was $85.80 \mathrm{mg} / \mathrm{dl}$ and after dinner was $110 \mathrm{mg} / \mathrm{dl}$, $3 \mathrm{AM}$ was $79.68 \mathrm{mg} / \mathrm{dl}$ and next day fasting was 86.72 $\mathrm{mg} / \mathrm{dl}$.

Table 2: Mean plasma glucose levels before treatment in each group.

\begin{tabular}{|c|c|c|}
\hline \multirow[t]{2}{*}{ Mean } & \multicolumn{2}{|c|}{$\begin{array}{l}\text { Plasma glucose before treatment } \\
(\mathrm{mg} / \mathrm{dl})\end{array}$} \\
\hline & Glibenclamide group & Insulin group \\
\hline Fasting & 107 & 108 \\
\hline Postprandial & 142 & 141 \\
\hline Before lunch & 103 & 103 \\
\hline After lunch & 139 & 142 \\
\hline $\begin{array}{l}\text { Before } \\
\text { dinner }\end{array}$ & 105 & 106 \\
\hline After dinner & 140 & 141 \\
\hline
\end{tabular}

Table 4 shows the mean plasma glucose level before delivery in each group.

In glibenclamide group fasting was $87.62 \mathrm{mg} / \mathrm{dl}$, postprandial was $116.44 \mathrm{mg} / \mathrm{dl}$, before lunch was 95.62 $\mathrm{mg} / \mathrm{dl}$, after lunch was $115.80 \mathrm{mg} / \mathrm{dl}$, before dinner was $91.96 \mathrm{mg} / \mathrm{dl}$ and after dinner was $116.64 \mathrm{mg} / \mathrm{dl}, 3 \mathrm{AM}$ was $84.42 \mathrm{mg} / \mathrm{dl}$ and next day fasting was $86.30 \mathrm{mg} / \mathrm{dl}$ in comparison with insulin where fasting was $85.54 \mathrm{mg} / \mathrm{dl}$, postprandial was $114.14 \mathrm{mg} / \mathrm{dl}$, before lunch was 87.08 $\mathrm{mg} / \mathrm{dl}$, after lunch was $112.82 \mathrm{mg} / \mathrm{dl}$, before dinner was $86.76 \mathrm{mg} / \mathrm{dl}$ and after dinner was $114.18 \mathrm{mg} / \mathrm{dl}, 3 \mathrm{AM}$ was $81.16 \mathrm{mg} / \mathrm{dl}$ and next day fasting was $86.72 \mathrm{mg} / \mathrm{dl}$. It is statistically significant.

Table no 5 shows that total $8(08 \%)$ patients had hypoglycaemia, in glibenclamide group $02(04 \%)$ had hypoglycaemia, whereas in insulin group 06 (12\%) patients had hypoglycaemia, $50(100 \%)$ patients were compliant and accepted glibenclamide, where as in insulin only $10(20 \%)$ had good compliance level, 19 $(38 \%)$ patients were moderately compliant with treatment and $21(42 \%)$ had poor comfort level with insulin,02 (04 $\%)$ patients could not achieve the adequate glycaemic control and were shifted to insulin treatment and the mean cost of treatment with glibenclamide was 79.32 INR and with insulin is 1126.40 INR 
Table 3: Mean plasma glucose levels after 1 week of treatment in each group.

\begin{tabular}{|c|c|c|c|c|c|c|}
\hline Group & Mean & Std. Deviation & $\begin{array}{l}\text { Mean } \\
\text { Difference }\end{array}$ & $\begin{array}{l}\mathrm{T} \\
\text { test }\end{array}$ & P value & Result \\
\hline Glibenclamide (Fasting) & 91.20 & 6.44 & \multirow{2}{*}{6.04} & \multirow{2}{*}{3.818} & \multirow{2}{*}{0.000} & \multirow{2}{*}{ Significant } \\
\hline Insulin (Fasting) & 85.16 & 7.25 & & & & \\
\hline Glibenclamide (Postprandial) & 117.38 & 7.96 & \multirow{2}{*}{5.26} & \multirow{2}{*}{2.996} & \multirow{2}{*}{0.003} & \multirow{2}{*}{ Significant } \\
\hline Insulin (Postprandial ) & 112.12 & 9.52 & & & & \\
\hline Glibenclamide (Before lunch) & 94.06 & 8.35 & \multirow{2}{*}{7.36} & \multirow{2}{*}{3.838} & \multirow{2}{*}{0.000} & \multirow{2}{*}{ Significant } \\
\hline Insulin (Before lunch) & 86.70 & 10.68 & & & & \\
\hline Glibenclamide (After lunch) & 114.68 & 9.07 & \multirow{2}{*}{3.66} & \multirow{2}{*}{1.923} & \multirow{2}{*}{0.049} & \multirow{2}{*}{ Significant } \\
\hline Insulin (After lunch) & 111.02 & 9.94 & & & & \\
\hline Glibenclamide (Before dinner) & 92.38 & 8.92 & \multirow{2}{*}{6.58} & \multirow{2}{*}{3.831} & \multirow{2}{*}{0.000} & \multirow{2}{*}{ Significant } \\
\hline Insulin (Before dinner) & 85.80 & 8.24 & & & & \\
\hline Glibenclamide (After dinner) & 115.52 & 10.82 & \multirow{2}{*}{5.52} & \multirow{2}{*}{2.630} & \multirow{2}{*}{0.010} & \multirow{2}{*}{ Significant } \\
\hline Insulin (After dinner) & 110.00 & 10.16 & & & & \\
\hline Glibenclamide (3 AM) & 82.68 & 5.49 & \multirow{2}{*}{3} & \multirow{2}{*}{2.553} & \multirow{2}{*}{0.012} & \multirow{2}{*}{ Significant } \\
\hline Insulin (3 AM) & 79.68 & 6.23 & & & & \\
\hline $\begin{array}{l}\text { Glibenclamide (Next day } \\
\text { fasting) }\end{array}$ & 86.28 & 6.41 & \multirow{2}{*}{-0.44} & \multirow{2}{*}{$\overline{0}-386$} & \multirow{2}{*}{0.701} & \multirow{2}{*}{$\begin{array}{l}\text { Not } \\
\text { Significant }\end{array}$} \\
\hline Insulin (Next day fasting) & 86.72 & 4.90 & & & & \\
\hline
\end{tabular}

Table 4: Mean plasma glucose levels before delivery/termination of pregnancy in each group.

\begin{tabular}{|c|c|c|c|c|c|c|}
\hline Group & Mean & Std. Deviation & Mean Difference & T test & P value & Result \\
\hline $\begin{array}{l}\text { Glibenclamide } \\
\text { (Fasting) }\end{array}$ & 87.62 & 4.73 & \multirow[t]{2}{*}{2.08} & \multirow[t]{2}{*}{2.201} & \multirow[t]{2}{*}{0.030} & \multirow[t]{2}{*}{ Significant } \\
\hline Insulin (Fasting) & 85.54 & 4.72 & & & & \\
\hline Glibenclamide (Postprandial) & 116.44 & 4.98 & \multirow[t]{2}{*}{2.3} & \multirow[t]{2}{*}{2.495} & \multirow[t]{2}{*}{0.014} & \multirow[t]{2}{*}{ Significant } \\
\hline Insulin (Postprandial) & 114.14 & 4.21 & & & & \\
\hline Glibenclamid (Before lunch) & 95.62 & 6.42 & \multirow[t]{2}{*}{8.54} & \multirow[t]{2}{*}{5.964} & \multirow[t]{2}{*}{0.000} & \multirow[t]{2}{*}{ Significant } \\
\hline Insulin (Before lunch) & 87.08 & 7.83 & & & & \\
\hline Glibenclamide (After lunch) & 115.80 & 6.56 & \multirow[t]{2}{*}{2.98} & \multirow[t]{2}{*}{2.331} & \multirow[t]{2}{*}{0.022} & \multirow[t]{2}{*}{ Significant } \\
\hline Insulin (After lunch) & 112.82 & 6.23 & & & & \\
\hline Glibenclamide (Before dinner) & 91.96 & 7.85 & \multirow[t]{2}{*}{5.2} & \multirow[t]{2}{*}{3.960} & \multirow[t]{2}{*}{0.000} & \multirow[t]{2}{*}{ Significant } \\
\hline Insulin (Before dinner) & 86.76 & 4.96 & & & & \\
\hline Glibenclamide (After dinner) & 116.64 & 6.84 & \multirow[t]{2}{*}{2.46} & \multirow[t]{2}{*}{1.930} & \multirow[t]{2}{*}{0.003} & \multirow[t]{2}{*}{ Significant } \\
\hline Insulin (After dinner) & 114.18 & 5.65 & & & & \\
\hline Glibenclamide (3 AM) & 84.42 & 3.92 & \multirow[t]{2}{*}{2.26} & \multirow[t]{2}{*}{2.367} & \multirow[t]{2}{*}{0.003} & \multirow[t]{2}{*}{ Significant } \\
\hline Insulin (3 AM) & 81.16 & 5.21 & & & & \\
\hline $\begin{array}{l}\text { Glibenclamide (Next day } \\
\text { fasting) }\end{array}$ & 86.30 & 5.01 & -0.7 & -0.716 & 0.475 & $\begin{array}{c}\text { Not } \\
\text { Significant }\end{array}$ \\
\hline
\end{tabular}

Table 5: Comparison of outcome of treatment.

\begin{tabular}{|c|c|c|c|}
\hline Treatment outcome & Glibenclamide group ( $\mathrm{n=50}$ ) & Insulin group $(\mathbf{n = 5 0})$ & Total $(\mathrm{n}=\mathbf{1 0 0})$ \\
\hline Hypoglycaemia & $02(04)$ & $06(12)$ & $08(08)$ \\
\hline \multicolumn{4}{|l|}{ Compliance } \\
\hline Good & $50(100)$ & $10(20)$ & $60(60)$ \\
\hline Average & - & $19(38)$ & $19(19)$ \\
\hline Poor & - & $21(42)$ & $21(21)$ \\
\hline Failure of treatment ( shift to insulin ) & $02(04)$ & - & - \\
\hline Cost & 79.32 INR & 1126 INR & - \\
\hline
\end{tabular}


Table no 6 shows that the overall incidence of hypertensive disorder was $04 \%$ and $03(06 \%)$ patient developed hypertension in glibenclamide group and 01 $(02 \%)$ in insulin group,total $10(10 \%)$ patients had preterm delivery, $04(08 \%)$ and $06(12 \%)$ had preterm delivery in glibenclamide and insulin groups.72 (72\%) patients had normal delivery, 04 (04\%) patients had instrumental delivery and 24 (24\%) had caesarean delivery. In glibenclamide group, $34(68 \%)$ patients had normal delivery, $04(08 \%)$ patients had instrumental delivery and 12 (24\%) patients had caesarean delivery, whereas in insulin group $38(76 \%)$ patients had normal delivery and 12 (24\%) patients had caesarean delivery.

Table 6: Comparison of fetal outcome in each group.

\begin{tabular}{|llll|}
\hline Outcome & Glibenclamide group $(\mathrm{n}=50)$ & Insulin group $(\mathbf{n = 5 0})$ & Total $(\mathbf{n = 1 0 0 )}$ \\
\hline Intrauterine fetal demise & $01(02 \%)$ & - & $01(01 \%)$ \\
\hline Intrauterine growth restriction & $02(04 \%)$ & $01(02 \%)$ & $03(03 \%)$ \\
\hline Macrosomia & $01(02 \%)$ & - & $01(01 \%)$ \\
\hline Respiratory distress syndrome & - & $01(02 \%)$ & $01(01 \%)$ \\
\hline Neonatal hypoglycemia & $01(02 \%)$ & $03(06 \%)$ & $04(04 \%)$ \\
\hline Hyperbilirubinemia & $09(18 \%)$ & $09(18 \%)$ & $18(18 \%)$ \\
\hline
\end{tabular}

Table 7: Comparison of maternal outcome in each group.

\begin{tabular}{|ll|ll}
\hline Outcome & Glibenclamide group $(\mathbf{n = 5 0})$ & Insulin group $(\mathbf{n = 5 0})$ & Total $(\mathbf{n = 1 0 0 )}$ \\
\hline Hypertensive disorders & $03(06 \%)$ & $01(02 \%)$ & $04(04 \%)$ \\
\hline Preterm delivery & $04(08 \%)$ & $06(12 \%)$ & $10(10 \%)$ \\
\hline Mode of delivery & & $38(76 \%)$ & $72(72 \%)$ \\
\hline Normal delivery & $34(68 \%)$ & - & $04(04 \%)$ \\
\hline Instrumental delivery & $04(08 \%)$ & $12(24 \%)$ & $24(24 \%)$ \\
\hline Caesarean & $12(24 \%)$ & & \\
\hline
\end{tabular}

Table no 7 shows that overall incidence of intrauterine fetal demise was $01 \%$ which was seen in glibenclamide group and the calculated chi test value was 0 , df was 1 and $p$ value was 1 , which implies no significant statistical association of intrauterine foetal demise with glibenclamide. The incidence of IUGR $03 \%, 02(04 \%)$ in glibenclamide group and $01(02) \%$ in insulin group and macrosomia was $01 \%$ and in glibenclamide group it was $02 \%$.The incidence of RDS was $01 \%$, which was present only in insulin group. Neonatal hypoglycaemia was noted in $04(04 \%)$ nenates , $01 \quad(02 \%)$ in glibenclamide and $03(06 \%)$ in insulin group.18 $(18 \%)$ neonates developed hyperbilirubinemia after delivery, 09 (18\%) neonates developed hyperbilirubinemia in both group.

\section{DISCUSSION}

Pregnancy is a time of increasing insulin resistance because of great hormonal changes. Gestational diabetes ensues when the women's insulin secretory capacity is inadequate to overcome the insulin resistance which is more often associated with overweight and advanced age and previous complicated obstetric history. Early diagnosis, adequate treatment and follow-up are vital in successfully managing these patients. This study was conducted at Command Hospital Air Force, Bangalore, a premium Institute of Indian Defence Services providing tertiary care facilities to all defence personnel and their dependent family members, who hail from different ethnic groups and cultural diversity prevailing over the whole of Indian subcontinent. This study was an attempt to find out the effectiveness of glibenclamide over insulin in achieving adequate glycaemic control, assess the maternal and foetal outcomes in treated patients of GDM, to determine the failure rate of glibenclamide and establish the compliance and comfort level and cost of the treatment.

The age of the patients in this study ranged from 23 to 33 years. The mean age in glibenclamide group was 27.32 $(\mathrm{SD} \pm 2.84)$ where as in insulin group was 26.30 $(\mathrm{SD} \pm 3.01)$.

In our study, the mean plasma glucose level before treatment in glibenclamide group- fasting was $107 \mathrm{mg} / \mathrm{dl}$, post prandial was $142 \mathrm{mg} / \mathrm{dl}$, before lunch was $103 \mathrm{mg} / \mathrm{dl}$, after lunch was $139 \mathrm{mg} / \mathrm{dl}$, before dinner was $105 \mathrm{mg} / \mathrm{dl}$ and after dinner was $140 \mathrm{mg} / \mathrm{dl}$ and whereas in insulin group- fasting was $108 \mathrm{mg} / \mathrm{dl}$, postprandial was $141 \mathrm{mg} / \mathrm{dl}$, before lunch was $103 \mathrm{mg} / \mathrm{dl}$, after lunch was $142 \mathrm{mg} / \mathrm{dl}$, before dinner was 106mg/dl and after dinner was $141 \mathrm{mg} / \mathrm{dl}$. The mean plasma glucose level after 1 week of treatment delivery in glibenclamide group fasting was $91.20 \mathrm{mg} / \mathrm{dl}$, postprandial was $117.38 \mathrm{mg} / \mathrm{dl}$, before lunch was $94.06 \mathrm{mg} / \mathrm{dl}$, after lunch was 114.68 
$\mathrm{mg} / \mathrm{dl}$, before dinner was $92.38 \mathrm{mg} / \mathrm{dl}$, after dinner was $115.52 \mathrm{mg} / \mathrm{dl}, 3 \mathrm{AM}$ was $82.68 \mathrm{mg} / \mathrm{dl}$ and next day fasting was $86.28 \mathrm{mg} / \mathrm{dl}$ whereas in insulin group- fasting was $85.16 \mathrm{mg} / \mathrm{dl}$, postprandial was $112.12 \mathrm{mg} / \mathrm{dl}$, before lunch was $86.70 \mathrm{mg} / \mathrm{dl}$, after lunch was $111.02 \mathrm{mg} / \mathrm{dl}$, before dinner was $85.80 \mathrm{mg} / \mathrm{dl}$ and after dinner was $110 \mathrm{mg} / \mathrm{dl}$, $3 \mathrm{AM}$ was $79.68 \mathrm{mg} / \mathrm{dl}$ and next day fasting was 86.72 $\mathrm{mg} / \mathrm{dl}$.

The mean plasma glucose level before delivery/termination in glibenclamide group-fasting was $87.62 \mathrm{mg} / \mathrm{dl}$, postprandial was $116.44 \mathrm{mg} / \mathrm{dl}$, before lunch was $95.62 \mathrm{mg} / \mathrm{dl}$, after lunch was $115.80 \mathrm{mg} / \mathrm{dl}$, before dinner was $91.96 \mathrm{mg} / \mathrm{dl}$ and after dinner was 113.64 $\mathrm{mg} / \mathrm{dl}, 3 \mathrm{AM}$ value was $82.42 \mathrm{mg} / \mathrm{dl}$ and next day fasting was $86.30 \mathrm{mg} / \mathrm{dl}$ in comparison with insulin where fasting was $85.54 \mathrm{mg} / \mathrm{dl}$, postprandial $114.14 \mathrm{mg} / \mathrm{dl}$, before lunch was $87.08 \mathrm{mg} / \mathrm{dl}$, after lunch was $112.82 \mathrm{mg} / \mathrm{dl}$, before dinner was $86.76 \mathrm{mg} / \mathrm{dl}$ and after dinner was 114.18 $\mathrm{mg} / \mathrm{dl}$, 3AM value was $81.16 \mathrm{mg} / \mathrm{dl}$ and next day fasting was $86.72 \mathrm{mg} / \mathrm{dl}$ in comparison to the Pavitra et al where they achieved plasma blood glucose level of fasting -82 $\mathrm{mg} / \mathrm{dl}$ and postprandial $107 \mathrm{mg} / \mathrm{dl}$ in glibenclamide group and fasting $89 \mathrm{mg} / \mathrm{dl}$ and postprandial $111 \mathrm{mg} / \mathrm{dl}^{8}$

In the present study, out of 50 patients, 02 (04) patients could not achieve the adequate glycaemic control and were shifted to insulin treatment. Failure rate was $4 \%$ in comparison to other studies Convey $\mathrm{S}$ et al, where the failure rate was $16 \% .^{9}$ Kremer and Duff, where the failure rate was $19 \%,{ }^{10}$ Chmait et al where the failure rate was $19 \%$, Jacobson et al, where the failure rate was $12 \%$, Langer et al the failure rate was $4 \% .^{3,10-12}$ Conversion rate was low in our study, as being a military hospital, women who come for antenatal care are fairly well educated and well informed. They come for regular follow up and also when glycaemic control was poor women were admitted for dose adjustment as well as close monitoring of diet and glycaemic control.

In the present study, total $8(08 \%)$ patients had hypoglycaemia, in glibenclamide group $02(04 \%)$ had hypoglycaemia, whereas in insulin group 06 (12\%) patients had hypoglycaemia in comparison to other studies Oded Langer, in which patients had hypoglycaemia ( 9 percent and 6 percent in insulin and glibenclamide respectively).

The mean cost of the treatment with glibenclamide was 79.32 INR and with insulin was 1126. 40 INR this finding shows that glibenclamide is significantly cheaper than insulin. In other study, Goetz compared the costs associated with glibenclamide versus insulin therapy. ${ }^{4}$ Glibenclamide was found to be significantly cheaper than insulin. The overall compliance with glibenclamide is $100 \%$.In the present study, total $04(04 \%)$ patient developed hypertensive disorders during the antenatal period. $03(06 \%)$ patients and $01(02 \%)$ patients developed hypertensive disorders in glibenclamide and insulin group respectively. In a study conducted by
Romero Gutierrez $\mathrm{G}$ et al in 2005, where the insulin resistance is assessed in the third trimester of the pregnancy did not have association with pregnancy induced hypertension and they recommend to carry out further investigations with prospective design and assessing insulin resistance. ${ }^{13}$

In the present study, total $10(10 \%)$ patients had preterm delivery, $04(08 \%)$ and $06(12 \%)$ had preterm delivery in glibenclamide and insulin groups respectively. This incidence of preterm deliveries is supported by study done by Chatzi et al, where they found a strong association between development of metabolic syndrome and subsequent preterm delivery. ${ }^{14}$

In the present study, $72(72 \%)$ patients had normal delivery, 04 (04\%) patients had instrumental delivery and $24(24 \%)$ had caesarean delivery. In glibenclamide group $34(68 \%)$ patients had normal delivery, $04(08 \%)$ patients had instrumental delivery and 12 (24\%) patients had caesarean delivery, whereas in insulin group 38 (76\%) patients had normal delivery and $12(24 \%)$ patients had caesarean delivery.

In our study, there was one intrauterine foetal demise, which implies no significant statistical association of intrauterine foetal demise with glibenclamide. The patient who had IUFD during the study was compliant and blood glucose were under control, the patient had additional risk factor of gestational hypertension with blood pressure in the range of $140-150 / 90-100 \mathrm{~mm} \mathrm{hg}$, the cause of IUD could not be related to glibenclamide and could be related to high recording of BP which is similar to study conducted by Subbalakshmi et al where they found that intrauterine fetal death could be associated with raised blood pressure in mothers with gestational diabetes mellitus. ${ }^{15}$

In our study, $03(03 \%)$ patients delivered a neonate weighing less than $2.5 \mathrm{~kg}$ and $01(01 \%)$ delivered a neonate weighing more than $4 \mathrm{~kg}$. In glibenclamide group $02(04 \%)$ patients delivered a neonate weighing less than $2.5 \mathrm{~kg}$ and $01(02 \%)$ patient delivered a neonate weighing more than $4 \mathrm{~kg}$. The mean birth weight was $3.07 \mathrm{~kg}$ in the glibenclamide group and $2.97 \mathrm{~kg}$ in the insulin group. There was no significant statistical association macrosomia or small for gestational age with glibenclamide.

In our study, incidence of neonatal hypoglycaemia was $04 \%$. It was $01(2 \%)$ patient in glibenclamide group and $03(06 \%)$ in insulin group. Neonatal hypoglycaemia can be caused by the persistence of foetal hyperinsulinemia after birth, particularly when GDM is poorly managed. Hyperinsulinism which persists after birth in absence of glucose supply, results in prolonged hypoglycaemia with varying degrees of severity. Insulin inhibits activation of metabolic pathways of glucose productions, which occurs naturally in healthy new-borns, and increases glucose consumption by tissues. The other cause of neonatal 
hypoglycaemia is maternal hyperglycaemia during labour, which stimulates the persistent excessive secretion of foetal insulin 1 to 2 hours after birth. Levels $<35 \mathrm{mg} / \mathrm{dl}$ (term pregnancy), <25 mg/dl (preterm) According to other studies the incidence of neonatal hypoglycaemia was $16.3 \%$ by Landon et al and $7.1 \%$ by Ostlund et al. ${ }^{16}$

In our study, $1(01 \%)$ neonate had respiratory distress syndrome in insulin group. It is generally recognised that new-borns of diabetic mothers are at risk of developing neonatal respiratory distress. There are three possible causes: premature birth, surfactant deficiency and caesarean section, which increase the risk particularly of transient tachypnea of new born due to delayed absorption of lung fluid. In one prospective study conducted by Piper J. M. et al, after stratification by gestational age, the risk of absence of PG in the amniotic fluid was higher in the poor glycaemic control group between 36 weeks and 37 weeks, there were no cases of HMD after 37 weeks. ${ }^{17}$

In our study, the incidence of hyperbilirubinemia after delivery was $18 \%$, neonates developed hyperbilirubinemia in both group hyperbilirubinemia has been traditionally studied as a neonatal complication of maternal diabetes, in the same way as other more serious events such as death or brachial plexus injuries. It is not a serious complication if non-toxic levels are treated. The danger is the risk of nuclear icterus, which is not classically reported in cases of diabetes. The incidence of neonatal hyperbilirubinemia in general population is $10.5 \%$ in the term group and $25.3 \%$ in the near-term group had significant hyperbilirubinemia and required phototherapy. In the study by Crowther et al, the proportion of infants with icterus requiring phototherapy was $9 \%$ in both treatment and the routine group 104 In the study by Landon et al, there was no difference in the rate of hyperbilirubinemia between the treatment groups: $9.6 \%$ versus $12.9 \% .^{18}$

\section{CONCLUSION}

Glibenclamide seems to be an effective drug in the treatment of pregnant women with GDM, in achieving adequate glycaemic control with less chance of hypoglycaemia, and with maternal and neonatal morbidities comparable to those of insulin. The incidence of hypoglycaemia with glibenclamide is less as compared to insulin (12\%). Failure rate is less $(4 \%)$. The cost for the treatment is significantly low. Compliance with glibenclamide is better than insulin. It is concluded that glibenclamide is effective as insulin in achieving adequate glycaemic control with lesser incidence of hypoglycaemia, with no significant maternal and foetal morbidity and mortality, cheaper and patient friendly.

Funding: No funding sources Conflict of interest: None declared
Ethical approval: The study was approved by the Institutional Ethics Committee

\section{REFERENCES}

1. Committee on Obstetric practice. Committee opinion no.504: screening and diagnosis of gestational diabetes mellitus. Obstet Gyncol. 2011;118(3):751-3.

2. American diabetic association gestational diabetes mellitus. Diabetes carev. 2004;27:S88-S90.

3. Langer O, Conway DL, Berkus MD, Xenakis EM, Gonzales O. A comparison of glyburide and insulin in women with gestational diabetes mellitus. Engl $\mathbf{J}$ Med. 2000;343:1134-8.

4. Goetzl L, Wilkins I. Glyburide compared to insulin for the treatment of gestational diabetes mellitus: a cost analysis J Perinatolog. 2002;22:403-6.

5. Anjalakshi, Balaji V, Seshiah V. A prospective study comparing insulin and glibenclamide in Asian Indian women. Diab Res Clini Prac.2007;76:474.

6. Partha M, Sankar BT, Amit K, Saha DP, Noori K. Oral hypoglycemic glibenclamide: can it be a substitute to insulin in the management of gestational diabetes mellitus? a comparative study. J South Asian Feder Obstet Gynecol. 2012;4:28.

7. Temple A, Mayanglambam RD. Glibenclamide as treatment option for gestational diabetes mellitus. J Obstet Gynaecol Res. 2013;1147-52.

8. Kalra P, Kachhwaha CP, Singh HV. Prevalence, of gestational diabetes mellitus and its outcome in western Rajasthan. Indian $\mathbf{J}$ Endocrinol Meta. 2013;17(4):677.

9. Conway DL, Gonzales O, Skiver D.Use of glyburide for the treatment of gestational diabetes: the San Aatonio experience. J Maternal Fetal Neonatal Med. 2004;15:515.

10. Kremer CJ. Glyburide for the treatment of gestational diabetes. Obstet Gynecol. 2004;190(5):1438.

11. Chmait R, Dinise T, Moore T. Prospective observational study to establish predictors of glyburide success in women with gestational diabetes mellitus. J Perinaatol. 2004;24:617-22.

12. Jacobson GF, Ramos GA, Ching JY, Kirby RS, Ferrara A, Field R. Comparison of glyburide and insulin for the management of gestational diabetes in large managed care organization. Am J Obstet Gynecol. 2005;193:118-24.

13. Romero Gutierrez G, Alvarez Cisneros JA, Ponce Ponce de Leon AL. [ Association between insulin resistance and pregnancy induced hypertension a case control study. Ginecol Obstet Mex. 2003;71:244-52.

14. Chatzi L, Plana E Metabolic syndrome in early pregnancy and risk of preterm birth. Am journal Epidemiol. 2009;170 (7): 829-36.

15. Monteiro G, Subbalakshmi NK, Pai SR. A study on clinical characteristics of gestational diabetes mellitus associated with intrauterine foetal death. Int J Biomed Res. 2014;5(1):28-30. 
16. Ostlund I, Hanson U, Bjorlund A, Eva N, Norlander E., and al. maternal and fetal outcomes if impaired glucose intolerance is not treated. Diabetes Care. 2003;26:2107-11.

17. Crowther CA, Hiller JE, Moss JR. Effect of treatment of gestational diabetes mellitus on pregnancy outcomes. N Eng J Med. 2005;352:247786.

18. Landon MB, Gabbe SG, Piana R, Mennuti MT, Main EK. Neonatal morbidity in pregnancy complicated by diabetes mellitus: predictive value of maternal glycaemic profiles. Am J Obstet Gynaecol. 1987;156(5):1089-95.

Cite this article as: Rao PS, Datta S, Prajwal S. A comparative study of using glibenclamide versus insulin in the treatment of gestational diabetes mellitus and its outcome. Int J Reprod Contracept Obstet Gynecol 2017;6:1518-25. 